\title{
EXAMINATION OF THE RELATIONSHIP BETWEEN JOB SATISFACTION LEVELS AND ORGANIZATIONAL COMMITMENTS OF TOURISM SECTOR EMPLOYEES: A RESEARCH IN THE SOUTHEASTERN ANATOLIA REGION OF TURKEY
}

\author{
TURİZM SEKTÖRÜ ÇALIŞANLARININ İŞ TATMINİ DÜZEYLERİ İLE ÖRGÜTSEL \\ BAĞLILIKLARI ARASINDAKİ İLISSKINNIN İNCELENMESİ: TÜRKIYYE'NIN \\ GÜNEYDOĞU ANADOLU BÖLGESINDE BİR ARAŞTIRMA
}

\section{Cenk AKSOY ${ }^{1}$ - Halil İbrahim ŞENGÜN² - Yunus YILMAZ ${ }^{3}$}

\begin{abstract}
In this study, it was aimed to determine the relationship between job satisfaction and organizational commitment perceptions of employees in organizations. A questionnaire with 54 questions was used apart from demographic variables to test the model. These questionnaires were distributed to employees working in four and five-star hotel businesses in the provinces in the Southeastern Anatolia region of Turkey, and 492 questionnaires were used for the analysis. The data obtained in the research were evaluated with the help of SPSS 18.0 statistical package program using various statistical methods and test techniques (frequency distribution, t-test, Anova and correlation) in accordance with the purpose of the research. The significance level was accepted as 0.05. As a result of the analyses performed, the relationships between job satisfaction and the dimensions of organizational commitment were examined, and it was determined that affective commitment and normative commitment had a positive linear relationship with employee satisfaction and a negative linear relationship with continuance commitment. In addition, it was also determined that job satisfaction levels of employees differed in terms of demographic variables.
\end{abstract}

Keywords: Job Satisfaction, Organizational Commitment, Tourism Sector

\section{$\ddot{O} z$}

$\mathrm{Bu}$ çalışmada örgütlerde çalışanların iş tatmini ve örgütsel bağlılık algıları arasındaki ilişkinin tespit edilmesi amaçlanmıştır. Modeli test etmek amacıyla demografik değişkenler dışında 54 soruluk bir anket kullanılmıştır. Bu anketler Türkiye’nin Güneydoğu bölgesi illerinde dört ve beş yıldızlı otel işletmelerinde çalışan personele dağıtılmış ve analiz için 492 anket kullanılmıştır. Araştırmada elde edilen veriler, araştırmanın amacı doğrultusunda çeşitli istatistik metot ve test teknikleri (frekans dağılımı, t-testi, Anova ve korelasyon) kullanılarak SPSS 18.0 istatistik paket programı yardımıyla değerlendirilmiştir. Anlamlılık düzeyi 0.05 olarak kabul edilmiştir. Yapılan analizler sonucunda iş tatmininin, örgütsel bağlılık boyutları ile arasındaki ilişkiler incelenmiş, duygusal ve normatif bağlılığın çalışan tatminiyle pozitif doğrusal, devam bağlılığı ile negatif doğrusal bir ilişkisinin olduğu tespit edilmiştir. Ayrıca çalışanların iş tatmin düzeylerinin demografik değişkenler açısından farklılaştığı tespit edilmiştir.

Anahtar Kelimeler: İş Tatmini, Örgütsel Bağlılık, Turizm Sektörü

\footnotetext{
${ }^{1}$ Arş.Gör., Dicle Üniversitesi Sivil Havacılık Yüksekokulu, drcenkaksoy@ gmail.com

2 Öğr.Gör., Dicle Üniversitesi İIBF İşletme Bölümü, ibrahim.sengun@dicle.edu.tr

3 Öğr.Gör., Dicle Üniversitesi İİBF İşletme Bölümü, yunus.yilmaz@dicle.edu.tr
} 


\section{INTRODUCTION}

It is very important for today's organizations to ensure the psychological and social satisfaction of employees. In addition, organizations have to improve the commitment of their employees with high satisfaction and efficiency to the organization to ensure that they stay in the organization and to increase their efficiency. It is very important that employees are satisfied with their work so that they can be committed to their organizations. Employees can work more efficiently in the atmosphere of satisfaction to be created, and this will also lead to increased profitability of the organization. Therefore, employees' commitment to their organization and satisfaction with their work are among the concepts that may be perhaps the most basic building blocks in the formation of a productive working environment. The motivations of employees increase in an organization with a high level of commitment and satisfaction while the motivations of employees decrease in an environment without them. The commitment of employees who are not satisfied with their jobs to the organization becomes weaker, such a situation can cause workers to leave their organizations, lack of continuity, and decrease in efficiency and performance (Kamer, 2001: 32; Ceylan and Şenyüz, 2003: 57; Erdil and Keskin, 2003).

Accommodation businesses with an important position in the tourism sector should develop themselves and have a human resource structure that is appropriate for change. It is an undeniable fact that human resources, which is one of the actors of the service sector and has great importance in terms of the tourism sector, and organizational commitment and job satisfaction factors make significant contributions to employee happiness and productivity depending on the changes in customer demand.

The purpose of this study is to examine the relationship between organizational commitment and satisfaction levels of employees working in accommodation businesses. For this purpose, the hotels in the center and the districts of Gaziantep, Şanlıurfa Diyarbakır, Mardin and Batman provinces were determined and an attempt to measure the viewpoint of employees on their job satisfaction and organizational commitment levels was made by random sampling method. In this research, in the determination of organizational commitment and job satisfaction levels of employees, the data were collected through the scales developed in previous studies and analyzed, and certain results related to the topic were obtained. With the findings obtained within the scope of the research, it was also aimed to be helpful to the owners and managers of accommodation businesses by providing data to relevant academicians.

Especially in recent years, a large number of new tourism investments have been made depending on the number of tourists in Gaziantep, Şanlıurfa, Diyarbakır and Mardin which are the most tourist attractions of the Southeastern Anatolia Region. Those who provide quality service among the new hotels opened in these provinces are generally preferred by tourists and these enterprises are least affected by the contraction in the tourism sector. In this context, the level of satisfaction and loyalty of employees who have key roles in customer satisfaction has been investigated.

Although the concepts of organizational commitment and job satisfaction have been examined in different combinations in different areas, the examination of these two concepts together and the application of these concepts in the five big cities of southeastern region of Turkey have been scarcely encountered. The study was considered necessary due to the fact that the tourism sector has an intensive working environment and that the concepts discussed in the research region have not been adequately investigated in this sector. Also it is thought that this study, in which the concepts of job satisfaction and sub-dimensions of organizational commitment were addressed together, will contribute to the literature of organizational behavior in the tourism sector. 
The research question of the study: Is there a significant relationship between organizational commitment and its sub-dimensions and job satisfaction in terms of tourism sector employees in Southeastern Anatolia Region of Turkey?

\section{LITERATURE REVIEW}

\section{Organizational Commitment}

Organizational commitment, which is seen as a frequently used concept especially in the field of organizational behavior, has become a focus on which researches have been carried out by academicians for many years. The studies carried out merge on a common point that the concept of organizational commitment expresses a psychological state that characterizes the relationships of employees with the organization (Güçlü, 2006: 8, Varol, 2010: 3). According to Meyer and Allen, who are believed to have made the most significant contributions to the studies carried out in this field, the concept of organizational commitment is defined as "a psychological state that ensures individual's commitment to the organization", and it is stated that organizational commitment consists of three components as affective commitment, continuance commitment and normative commitment (Meyer and Allen, 1991). According to O'Reilly and Chatman (1986: 492), organizational commitment is a psychological interest and commitment to the organization felt by the individual, which allows him/her to internalize organizational goals and values and to be adapted to the organization.

\section{Job Satisfaction}

Job satisfaction is one of the most important and most studied organizational behavior issues examined. According to Spector (1997), job satisfaction is the positive feelings that people feel towards their jobs. The fact that the individual is pleased with the job he/she does is related to job satisfaction. The fact that employees are satisfied with their job is very important both for themselves and for their organization. Job satisfaction refers to the levels of satisfaction of the physical, mental and social needs of employees in line with their expectations and is one of the most important conditions for them to be successful, happy and productive (Hoş and Oksay, 2015, 9). While job satisfaction provides positive effects such as being efficient and productive, job dissatisfaction causes employees to have negative effects such as withdrawing from the job, lack of continuity or leaving work (Greenberg and Baron, 1995).

\section{Job Satisfaction and Organizational Commitment Relationship}

While job satisfaction is related to the job-related feelings and attitudes of employees in their organizations, organizational commitment deals with the feelings and attitudes of employees towards the organization in general (Çetinkanat, 2002: 2-3, cited by. Yenihan, 2014, 175).

There are many studies regarding the presence of a positive relationship between organizational commitment and job satisfaction. In the researches carried out, job satisfaction and organizational commitment have effects enhancing each other. However, there are also studies reaching different results (Dağdeviren Gözen, 2007, 86, cited by. Örücü et al., 2010, 4).

Four models were developed to examine the relationship between organizational commitment and job satisfaction. These can be expressed as "job satisfaction leads to organizational commitment", "organizational commitment leads to job satisfaction", "job satisfaction and organizational commitment mutually affect each other" and "organizational commitment and job satisfaction are independent” (Bayrak Kök, 2006, 300).

From this point of view, we can develop the hypotheses of the research as the following; 
H1: There is a positive relationship between the job satisfaction and sub-dimensions of organizational commitment perceptions of the employees working in the tourism sector in the Southeastern Anatolia Region of Turkey

\section{RESEARCH}

The method of the research, data collection tools and analysis of data will be discussed in this part of the study.

4.1. Method of the Research: This study aims to measure the organizational commitment and job satisfaction of employees working in four and five-star hotel businesses operating in Gaziantep, Şanlıurfa Diyarbakır, Mardin and Batman provinces. The study samples were selected through random sampling method. The scales were distributed to 600 employees employed in the relevant hotels, 512 of them were returned, but 20 of them were not classified because the questions were not fully answered. The demographic variables were evaluated through the remaining 492 questionnaires using frequencies and percentages, and the organizational commitment and job satisfaction scale and the data were evaluated and interpreted with the $t$ test, anova (F) test, post hoc test and correlation analysis techniques in analyses. Cronbach alpha internal consistency coefficients were calculated to test the internal consistency of scales, and the internal consistency (Cronbach alpha) of the organizational commitment scale was 0.89 . The value shows a very high internal consistency. The internal consistency of the JSS-Job Satisfaction Scale determined by the Cronbach's alpha coefficient is 0.66. The internal consistency of the scale was found to be adequate.

4.2. Data Collection Tools: A scale of 61 items including 7 questions consisting of characteristics such as age, gender, educational status, marital status and work experience and 54 questions to measure commitment and job satisfaction was used in the collection of data. A 5-point Likert scale was used to determine to what extent the participants agreed the statements included in the questionnaire. Accordingly, the statements were listed as "Strongly Disagree (1)", "Disagree (2)", "Partially Agree (3)", "Agree (4)" and "Totally Agree (5)".

Organizational Commitment Scale: The "Organizational Commitment Scale" which was developed by Allen and Meyer (1990) and re-examined by Meyer, Allen and Smith (1993) was used to measure organizational commitment. This scale (Wasti, 2000), which is widely used and accepted in the literature in Turkey, consists of three dimensions, including affective commitment, continuance commitment and normative commitment, and 18 items. There are 6 items in each dimension. In the scale, items 3, 4, 5 and 13 include negative meanings and these items were reversely coded.

Job Satisfaction Scale: The Job Satisfaction Scale, which was developed by Spector (1985) and adapted to Turkish by Yelboğa (2009), was used with Job Satisfaction Survey (JSS). The scale consists of nine sub-dimensions including "Wage", "Promotional Opportunities", "Supervision", "Social Rights", "Performance Based Rewarding", "The Way the Work is Done", "Nature of the Work", "Business Structure" and "Communication", and a total of 36 items; and each dimension included four items.

4.3. Analysis of Data: SPSS 18.0 statistical program was used in the evaluation of the data. The data obtained in the research were interpreted using various statistical methods and test techniques in line with the purpose of the research. The evaluation of the data was performed based on the total scores of the answers the participants gave to each question. The statistical significance level was accepted as $\mathrm{p}<0.05$. 


\section{RESULTS}

Information regarding the demographic characteristics of the research participants are presented in Table 1. As it is seen in table 1 below, 492 people participated in the search; when the distribution of participants according to their departments was examined, $32 \%$ of hotel employees are working on the floors, $26 \%$ of them were working in public relations, $14 \%$ of them were working in the food and beverage department, $12 \%$ of them were working at the reception, $9 \%$ of them were working in the cleaning department and $8 \%$ of them were working in the accounting department. According to these results, the majority of the employees were working on the floors (32\%) and in public relations (28\%).

$45 \%$ of the participants were women, $55 \%$ of them were male. When the distribution of participants according to their age was examined, it was stated that $40 \%$ of employees were between the ages of $18-30,36 \%$ of them were between the ages of $31-35,14 \%$ of them were between the ages of $36-40,5 \%$ of them were between the ages of $41-45$, and $5 \%$ of them were 46 years and over. $76 \%$ of the participants consisted of middle-aged employees, in other words, aged between 18-35. When the distribution of participants according to their educational status was examined, it was seen that $22 \%$ of the employees were primary school graduates, $38 \%$ of them were high school graduates, $20 \%$ of them were tourism associate graduates, $19 \%$ of them had bachelor's degree in tourism, and $2 \%$ of them had postgraduate degree in tourism. When the marital status of the participants was examined, 55\% of employees were single and $45 \%$ of them were married. When the distribution of the participants according to total service period at the hotel was examined, it was seen that $22 \%$ of employees had a service period less than 1 year, $57 \%$ of them had a service period between $1-5$ years, $17 \%$ of them had a service period between 6-10 years, and 4\% of them had a service period between 11-20 years. When the service periods of the participants in their positions was examined, it was seen that $28 \%$ of employees were working less than 4 years, $26 \%$ of them were working between $4-7$ years, $19 \%$ of them were working between 8-11 years, and $27 \%$ of them were working for 12 years and above.

\section{Surveys}

5.1. General Evaluation of Organizational Commitment and Job Satisfaction

Within the scope of the research, it is remarkable that the majority of the employees who participated in the survey were single and in the 18-35 age range. In the survey group predominated by male employees, it also attracts the attention that they mostly consisted of primary and high school graduate groups. This situation was interpreted in relation with the departments where the questionnaire was applied (floors, cleaning, reception, food and beverage, etc.). While the employees in managerial and decision-making positions usually graduated from undergraduate and associate degree programs, other employees graduated from high school or lower educational institutions.

Table 1. Demographic Variables

\begin{tabular}{|l|c|c|l|c|c|}
\hline Departments & Frequency & $\begin{array}{c}\text { Percentage } \\
(\boldsymbol{\%})\end{array}$ & $\begin{array}{c}\text { Educational } \\
\text { Status }\end{array}$ & Frequency & $\begin{array}{c}\text { Percentage } \\
(\boldsymbol{\%})\end{array}$ \\
\hline Floors & 155 & 31,5 & Primary School & 107 & 21,7 \\
\hline Cleaning & 45 & 9,2 & High School & 185 & 37,6 \\
\hline Accounting & 37 & 7,5 & $\begin{array}{l}\text { Tourism } \\
\text { Associate } \\
\text { Graduate }\end{array}$ & 96 & 19,5 \\
\hline Reception & 61 & 12,4 & $\begin{array}{l}\text { Bachelor's } \\
\text { Degree in } \\
\text { Tourism }\end{array}$ & 92 & 18,7 \\
\hline
\end{tabular}




\begin{tabular}{|c|c|c|c|c|c|}
\hline $\begin{array}{l}\text { Public } \\
\text { Relations }\end{array}$ & 126 & 25,6 & Postgraduate & 12 & 2,4 \\
\hline $\begin{array}{l}\text { Food and } \\
\text { Beverage }\end{array}$ & 68 & 13,8 & Total & 492 & 100 \\
\hline Total & 492 & 100 & \multicolumn{3}{|c|}{ Total Service Period } \\
\hline \multicolumn{3}{|l|}{ Gender } & \begin{tabular}{|lll}
$\begin{array}{l}\text { Less } \\
\text { year }\end{array}$ & than & 1 \\
\end{tabular} & 108 & 22 \\
\hline Women & 219 & 44,5 & $1-5$ years & 280 & 57 \\
\hline Men & 273 & 55,5 & $6-10$ years & 84 & 17,1 \\
\hline Total & 492 & 100 & $11-20$ years & 20 & 4,1 \\
\hline \multicolumn{3}{|l|}{ Age } & Total & 492 & 100 \\
\hline $18-30$ & 199 & 40,4 & \multicolumn{3}{|c|}{\begin{tabular}{|l} 
Service Periods in the Position \\
\end{tabular}} \\
\hline $31-35$ & 175 & 35,5 & $\begin{array}{|lll|}\begin{array}{l}\text { Less than } \\
\text { years }\end{array} & \\
\end{array}$ & 138 & 28 \\
\hline $36-40$ & 69 & 14 & 4-7 Years & 130 & 26,4 \\
\hline $41-45$ & 25 & 5,1 & 8-11 Years & 93 & 18,9 \\
\hline 46 and over & 24 & 4,9 & $\begin{array}{l}12 \text { Years and } \\
\text { over }\end{array}$ & 131 & 26,6 \\
\hline Total & 492 & 100 & Total & 492 & 100 \\
\hline \multicolumn{6}{|l|}{ Marital Status } \\
\hline Married & 221 & 44,9 & & & \\
\hline Single & 271 & 55,1 & & & \\
\hline Total & 492 & 100 & & & \\
\hline
\end{tabular}

Furthermore, the following results were also reached as a result of the analyses of whether there was any difference in terms of organizational commitment and job satisfaction dimensions within the context of demographic variables.

It was determined that there was a differentiation in terms of the nature of the work of the job satisfaction dimensions with working department variable $(\mathrm{F}=2.678, \mathrm{p}<0.05)$. To which business department (position) this differentiation belonged was put to Post-hoc (multiple comparison) test, and the differentiation was determined to be random (Table 2).

Table 2. Job Satisfaction Dimensions with Working Department Variable (ANOVA)

\begin{tabular}{lccccc}
\hline Nature of the Work & $\begin{array}{c}\text { Sum of } \\
\text { Squares }\end{array}$ & df & Mean Square & F & Sig. \\
\hline Between Groups & 10,716 & 5 & 2,143 & 2,678 & 0,031 \\
\hline Within Groups & 96,944 & 486 & 0,199 & & \\
\hline Total & 107,660 & 491 & & & \\
\hline
\end{tabular}

It was determined that there was a differentiation in terms of continuance commitment with the marital status and that this differentiation was in favor of women employees $(\bar{X}=$ 3.421) $(\mathrm{t}=-2.213 ; \mathrm{p}<0.05)$.

It was determined that there was a differentiation in terms of job satisfaction promotion dimension with the age variable $(\mathrm{F}=2.634 ; \mathrm{p}<0.05)$. To which age group this differentiation belonged was put to Post-hoc (multiple comparison) test, and the differentiation was determined to be random (Table 3). 
Table 3. Age Variable and Job Satisfaction Dimensions (ANOVA)

\begin{tabular}{lccccc}
\hline Promotion Dimension & $\begin{array}{c}\text { Sum of } \\
\text { Squares }\end{array}$ & df & Mean Square & F & Sig. \\
\hline Between Groups & 6,528 & 4 & 1,632 & 2,634 & 0,035 \\
\hline Within Groups & 58,908 & 487 & 0,120 & & \\
\hline Total & 65,436 & 491 & & & \\
\hline
\end{tabular}

It was determined that there was a differentiation in terms of the nature of the work dimension with service period in the position variable $(\mathrm{F}=3.579 ; \mathrm{p}<0.05)$. To which service period in the position variable this differentiation belonged was put to Post-hoc (multiple comparison) test, and the differentiation was determined to be random (Table 4).

Table 4. Service Period in the Position Variable and Job Satisfaction Dimensions (ANOVA)

\begin{tabular}{lccccc}
\hline Nature of the Work & $\begin{array}{c}\text { Sum of } \\
\text { Squares }\end{array}$ & df & Mean Square & F & Sig. \\
\hline Between Groups & 11,764 & 3 & 3,921 & 3,579 & 0,008 \\
\hline Within Groups & 95,84 & 488 & 0,196 & & \\
\hline Total & 107,604 & 491 & & & \\
\hline
\end{tabular}

In the correlation analyses performed, it was determined that commitment had a positive linear strong relationship with its dimensions. In this context, commitment is associated with its affective dimension $(0.864 ; \mathrm{p}<00.1)$, continuance dimension $(0.729 ; \mathrm{p}<00.1)$ and normative dimension $(0.889 ; \mathrm{p}<00.1)$, and it was determined that the strongest relationship was with the normative dimension.

When the relationship between job satisfaction and the dimensions of commitment (table 5) was examined, it was determined that there was a strong linear relationship between the affective (0.65) and normative (0.67) commitments, which are the dimensions of commitment, and there was a weak linear relationship in terms of continuance $(0.29)$ commitment.

Table 5.11. Relationship Between Job Satisfaction and Organizational Commitment Dimensions

\begin{tabular}{|c|c|c|c|c|c|}
\hline & & 1 & 2 & 3 & 4 \\
\hline 1.Job Satisfaction & \multirow{4}{*}{$\begin{array}{l}\text { Correlation } \\
\text { Coefficient }\end{array}$} & 1 & & & \\
\hline 2.Affective Commitment & & $0,653 * *$ & 1 & & \\
\hline 3.Continuance Commitment & & $0,292 * *$ & $0,387 * *$ & 1 & \\
\hline 4.Normative Commitment & & $0,668 * *$ & $0,712 * *$ & $0,495^{* *}$ & 1 \\
\hline
\end{tabular}

As it is seen in this table, there is a positive linear relationship between job satisfaction and two of the three sub-dimensions of organizational commitment $(\mathrm{p}<0.001)$. Hence, the hypothesis $\mathbf{H}_{1}$ : "There is a positive relationship between the job satisfaction and subdimensions of organizational commitment perceptions of the employees working in the tourism sector in the Southeastern Anatolia Region of Turkey" is partially accepted.

When the relationship between commitment and the dimensions of job satisfaction was examined, it was determined that the Wage dimension $(0.68 ; \mathrm{p}<0.01)$, Rewarding $(0.61$; $\mathrm{p}<0.01)$ Group of Friends $(0.65 ; \mathrm{p}<0.01)$ and Communication $(0.673 ; \mathrm{p}<0.01)$ dimensions of the sub-dimensions of job satisfaction had a positive, linear, strong relationship with organizational commitment, and that the Nature of the Work $(0.267 ; \mathrm{p}<0.01)$ and Supervision 
$(0.334 ; \mathrm{p}<0.01)$ dimensions had a positive, linear, weak relationship with organizational commitment.

In addition, it was also determined that there was a negative linear weak relationship with commitment in terms of the Social Rights $(-0.210$; $\mathrm{p}<0.05)$ and the Way the Work is Done $(-0.353 ; \mathrm{p}<0.01)$ dimensions, and that there was no relationship between the Promotion Dimension $(0.00 ; \mathrm{p}>0.01)$ and organizational commitment.

When a general understanding is put forward according to the results obtained from the research, it can be stated that the employees of the hotel work in a harmonious and happy manner in the sector, that their work mates and working environments are good $(\bar{X}=4.2)$, that individual productivity is high and that the sense of adopting the business is developed. Besides, it appears that there are a number of shortcomings especially in the actions increasing the social satisfaction level and in working conditions.

\section{CONCLUSION}

In the study, the relationship between job satisfaction and organizational commitment was investigated. As a result of the research, results that partially supported the research problem were obtained. The results obtained within the scope of the tests and analyses performed in the research are stated below.

In the research carried out, while it was determined that there was a positive linear relationship between job satisfaction and affective and normative commitment of the dimensions of the organizational commitment, it was seen that there was a positive, linear, weak relationship between job satisfaction and continuance commitment.

In this study, it was assumed that that the high level of job satisfaction of the employees in the hotel businesses would create a commitment to the business where the employees work, so better quality of service would be provided to the customers.

It was seen as a result of the literature review that there is no complete consensus about the relationship between job satisfaction and organizational commitment discussed in the study. It was seen that the results obtained were similar to some previous studies in the literature.

Similar to this study Çele at al. (2013) found that increase in "Affective Commitment" and "Normative Commitment" levels of employees, increases their level of job satisfaction. They also emphasized that "Continuance Commitment, which is the most undesirable type of commitment for organizations, has no effect or has a negative effect on job satisfaction."

Hoş and Oksay (2015) found that 'Affective Commitment', 'Continuance Commitment' and 'Normative Commitment', which form subdimensions of organizational commitment, are highly related to job satisfaction in their research.

In Varol's study (2017), it is seen that the relationship between job satisfaction and organizational commitment components is significant and positive. In his study of the relationship between organizational commitment components and job satisfaction, he stated that the increase in job satisfaction levels of occupants also increases their level of organizational commitment.

The fact that this study was limited to some of the Southeastern provinces, that limited number of questionnaires were applied and that the businesses that were included within the scope of the research had time and space limitations can be considered among the main limitations. In addition, the fact that the evaluation of concepts such as job satisfaction and commitment was based on perceptions of employees rather than objective evaluations as in 
other questionnaire studies and that there is no certain consensus in the literature concepts is another limitation.

With this study applied in the tourism sector, some suggestions that should be discussed carefully have been presented to businesses and managers operating in this field. These suggestions can be summarized as the following;

Job satisfaction of employees is directly affected by the factors such as the physical possibilities of the workplace, human relations, sound financial and social facilities. Therefore, in order to increase the satisfaction levels of the employees, it is necessary to first estimate their expectations and to respond to their needs at the required level.

The organizational commitment level of employees varies depending on the factors such as good interpersonal relations in businesses, offering opportunities such as rewards, bonuses and promotions to employees according to their talents and performances, making employees feel they are valued, presentation of social opportunities and organizing social activities. In addition, to provide tools/materials necessary to give the best service is another factor that increases employee satisfaction and organizational commitment.

Within the scope of the research, it is remarkable that the majority of the employees who participated in the survey were single and in the 18-35 age range. In the survey group predominated by male employees, the employees in manager and decision-making positions generally graduated from undergraduate and associate degree programs while other employees graduated from high school or lower educational institutions.

\section{REFERENCES}

Bayrak Kök, S. (2006). İş Tatmini ve Örgütsel Bağl1lı̆̆ın İncelenmesine Yönelik Bir Araştırma, İktisadi ve İdari Bilimler Dergisi, Cilt: 20 Nisan 2006, 20, (1), s. 291-318.

Ceylan, A. and Şenyüz, P. B. (2003). Örgütsel Destek Algısı ve Dahil Olma-Dışlanma Algısının Örgütsel Bağlılığa Etkisi-Sigorta Sektöründe Bir Araştırma, Yönetim Dergisi, 14 (44).

Çelen, Ö., Teke, A., and Cihangiroğlu, N. (2013). Örgütsel Bağlılığın İş Tatmini Üzerine Etkisi: Gülhane Askeri Tıp Fakültesi Eğitim Hastanesinde Bir Araştırma. Süleyman Demirel Üniversitesi, I.I.B.F. Dergisi, 18 (3).

Çetinkanat, C. (2000). Örgütlerde Güdüleme ve İş Doyumu, Anı Yayıncılık, Ankara.

Dağdeviren Gözen, E. (2007) İş Tatmini Ve Örgütsel Bă̆lllık Sigorta Şirketleri Üzerine Bir Uygulama, Atılım Üniversitesi, Sosyal Bilimler Enstitüsü Yayınlanmamış Yüksek Lisans Tezi, Ankara.

Greenberg, J. and Baron, R. A. (1995). Behavior in Organizations: Understanding and Managing the Human Side of Work. Fifth Edition. New Jersey: Prentice-Hall International Inc.

Güçlü, H. (2006). Turizm Sektöründe Durumsal Faktörlerin Örgütsel Bağl1lık Üzerindeki Etkisi, Anadolu Üniversitesi Yayınları, Eskişehir.

Erdil O. and Keskin H. (2013). Güçlendirmeyle İş Tatmini, İş Stresi ve Örgütsel Bağlılık Arasındaki İlişkiler, İstanbul Üniversitesi İşletme Fakültesi Dergisi, 32 (1).

Hoş, C. and Oksay, A. (2015). Hemşirelerde Örgütsel Bağl1lık ile İş Tatmini İlişkisi, Süleyman Demirel Üniversitesi İktisadi ve İdari Bilimler Fakültesi Dergisi 20 (4), s.1-24.

Kamer, M. (2001). Örgüte Güven, Örgüte Băglllık ve Örgütsel Vatandaşlık Davranışlarına Etkileri. Yayımlanmamış Yüksek Lisans Tezi. İstanbul: MÜ. Sosyal Bilimler Enstitüsü.

Meyer, J. P. and Allen, N. J. (1991). A Three Component Conceptualization of Organizational Commitment, Human Resources Management Review, Vol.1, pp. 61-89.

Meyer, J. P. and Allen, N. J. (1997). Commitment in the Workplace: Theory, Research and Application, Sage, Tousand Ouks, Ca. 
Meyer, J. P., Allen, N. J. and Smith, C. (1993). Commitment to Organizations and Occupations: Extension and Test of a Three-component Conceptualization, Journal of Applied Psychology, Vol. 78, pp. 538-551.

O'Reilly, C. A. and Chatman, J., (1986). Organizational Commitment and Psychological Attachment: The Effects of Compliance, Identification and Internalization on Prosocial Behaviour, Journal of Applied Psychology, No 71.

Örücü, E., Kılıç, R., Şimşir, S. (2010). Organizasyonlarda İş Tatmini Uygulamaları ve Örgütsel Bağlılığa Etkisi Üzerine Bir Araştırma, Yönetim ve Ekonomi Araştırmaları Dergisi, Y.2010, S.13, s.1-14.

Spector, P. E. (1985). Measurement of Human Service Staff Satisfaction: Development of the Job Satisfaction Survey. American Journal of Community Psychology, 13(6), 693-713.

Spector, P. E. (1997). Job Satisfaction: Application, Assessment, Cause and Consequences. Thousand Oaks: Sage Publications.

Varol, F. (2010). Örgütsel bağlılık ve İş Tatminin İşten Ayrılma Niyetine Olan Etkisi: Konya İli İlaç Sektörü Çalışanları Üzerine Bir Uygulama. Yüksek Lisans Tezi. SÜ. Sosyal Bilimler Enstitüsü.

Varol, F. (2017). Çalışanların Örgütsel Bağlılık ve İş Tatminlerinin İşten Ayrılma Niyetlerine Olan Etkisi: İlaç Sektörü Örneği, Selçuk Üniversitesi Sosyal Bilimler Enstitüsü Dergisi, (38), 200-208.

Wasti, A. (2000). "Örgütsel Bağlılı̆̆1 Belirleyen Evrensel ve Kültürel Etmenler: Türk Kültürüne Bir Bakıs, Türkiye’de Yönetim, Liderlik ve İnsan Kaynakları Uygulamaları”, (Eds.)

Yelboğa, A. (2009). Validity and reliability of the Turkish version of the job satisfaction survey (JSS), World Applied Sciences Journal, 6 (8), 1066-1072.

Yenihan, B. (2014). Örgütsel Bağlılık ve İş Tatmini Arasındaki İlişki, Karabük Üniversitesi Sosyal Bilimler Enstitüsü Dergisi, 4 (2), 2014, 170-178. 